\title{
Evidence-based teaching (EBT) and health librarians: some questions and considerations
}

\author{
Dean Giustini
}

\section{Introduction}

Evidence-based teaching...might be described as a growing, international movement in education that encourages teachers and educators to seek out, appraise and apply the best evidence from the literature when confronted with decisions that affect learners [1].

This is the fourth and final column in the teaching and learning series [2-4]. Its purpose is to consider some relevant questions associated with evidence-based teaching (EBT) and how best to use the evidence to improve our teaching programs. As Crumley and Koufogiannakis suggest, evidence-based librarianship is a means to improve our information practices by asking the right questions and by finding answers in the library literature [5]. This paper contends, however, that the evidence in teaching cannot (and should not) be viewed in isolation but viewed in a broader context of learning theory and knowledge of our users.

Teaching in librarianship goes back to the 19th century at least, though it has been known as bibliographic instruction for several decades [6]. Since the 1990s, growing interest in the effectiveness of library instruction has led to a variety of studies [7-9], but some of these have been duly criticized for variable quality. In addition, what seems missing is some investigation into what skills health librarians can bring to evidence-based practice (EBP) beyond information retrieval. Often, our involvement in EBP seems to begin and end with searching even though many of us have sought ways to break out of the searching constraint.

With that said, the evidence-based library and information practice (EBLIP) movement has looked from various angles at how we teach information skills. In 2006, Koufogiannakis and Wiebe looked specifically at undergraduates, but their meta-analysis found that computerassisted instruction was just as effective as traditional classroom teaching [9]. In 2008, Brettle, a health librarian, performed a systematic review of instructional training; she evaluated 24 studies measuring the effectiveness of workshops and teaching and whether this work had a positive impact on patient care [10]. Even though there was insufficient evidence to show this teaching improved patient outcomes, it revealed that the quality of the literature was poor. If we are to practice EBT, health librarians must work to improve the evidence-base in our field and conduct research regularly.

Partridge suggests that "librarians can engage in their own evidence-based teaching by continually questioning, reviewing and examining their approaches" [11]. To begin, we should share more of our strategies and "what works", as case studies. In the long term, case studies can only take us so far in measuring our effectiveness in the classroom. Finding the energy to do controlled experiments is one of the challenges we face at the frontlines of library services. The fact that conducting research takes time, expertise, and money that we don't always have doesn't make it easier-nor does the fact that many of us do not work within evidence-based cultures or get the requisite supports that are needed.

The emphasis throughout this series has been on how to use learning theories to structure teaching-but with an evaluation component to improve our ability to meet user needs. To examine and assess our teaching properly (an EBT activity in itself), health librarians should ask themselves some fundamental questions.

(i) What does it mean "to learn"? How can we measure learning?

(ii) What teaching methods are needed to be effective with busy health professionals?

(iii) What cognitive/affective and environmental factors must be considered for EBT?

(iv) What are the essential elements of effective teaching?

(v) Is there a way for us to formulate a list of EBT competencies?

In a practical sense, the first issue about what it means to learn is linked to our goals and objectives. How we develop teaching goals requires reflection. As stated at the outset, it is only within a sound teaching framework that health librarians can perform evidence-based assessment. Successful teaching is therefore not an accident (or based on a teacher's charm or alchemy with a class) but a result of reflection, planning, and assessment.

D. Giustini. Gordon and Leslie Diamond Health Care Centre, 2775 Laurel Street, Floor 2, Vancouver, BC V5Z 1M9, Canada; and School of Library, Archival and Information Studies (SLAIS), University of British Columbia, 1961 East Mall, Vancouver, BC V6T 1Z1, Canada (e-mail: dean.giustini@ubc.ca). 


\section{Evidence-based teaching (EBT)}

Teaching effective searching skills should be done at the "point of need" when the skills are needed to help make patient care decisions. Morning reports, clinical rounds, journal clubs or noon conferences are excellent opportunities to integrate teaching information-seeking skills with clinical knowledge [12].

There are few agreed upon definitions of EBT but a notable one is found in a monograph by Booth and Brice who quote the United States Department of Education: "...evidence based education is the integration of professional wisdom with the best empirical evidence in making decisions about how to deliver instruction" [13]. They argue that professional wisdom is equally important in creating empirical evidence, and while randomized trials are important, they should not be viewed as a panacea.

It will come as no surprise that EBT is related to its medical counterpart, evidence-based medicine (EBM). To review, EBM is the philosophical approach to improving health care decision-making made famous by Canadians Gordon Guyatt and David Sackett among others [14-15]. The five steps of EBM might be applied to EBT as follows:

(1) Formulate an answerable question about your learners and your teaching

(2) Systematically and comprehensively search electronic and print sources of information to find the best educational evidence

(3) Critically appraise the evidence and consider its applicability to your setting

(4) Organize and grade the quality of the evidence

(5) Assess its relevance to the learning needs of your users [16]

British educator Martyn Hammersley has criticized the EBT movement saying its advocates "treat teaching as the application of research-based knowledge alone and neglect the extent to which it involves uncertainties" [17]. In practice, health librarianship also involves uncertainties. To account for some of the ambiguities of our work, Booth devised a useful list of what he calls "consensually based" characteristics of evidence-based practice. They include the ability to ( $i$ ) consider the context of your day-to-day decision making; (ii) place a pragmatic focus on the best available evidence; (iii) try to incorporate user perspectives whenever feasible; (iv) understand the broad range of quantitative and qualitative study designs; and (v) know where to locate the evidence-based practice literature [18].

In addition to the skills listed by Booth, Peacock lists a number of important skills [19]. Health librarians can learn a great deal from this literature. By building your knowledge of learning theory and its application you are working towards your goal to be evidence-based practitioners. Booth's comment about placing a pragmatic focus on the best available evidence in the context of EBT seems to ring particularly relevant, and true [18].

\section{Evaluation and assessment}

Not surprisingly, evidence-based teachers take steps to evaluate how they do things. Some questions that might provide forward impetus for EBT might include the following:

(1) Do we know what our users' learning preferences and values are?

(2) What kind of evidence do we need to design our workshops?

(3) What learning opportunities (i.e., computer labs, classrooms, library, offices, wards, clinics) can we provide for our users and employ to examine whether learning is taking place?

(4) Are there resources that can help you in this process?

(5) Can we mentor our younger colleagues in their teaching given the vast experience that we should be passing on to new generations of health librarians?

Being acquainted with the scholarship of learning cannot be emphasized enough. One theory we have not discussed thus far is "andragogy" - the major theoretical contribution of American educator Malcolm Knowles [20]. To assist educators in designing classrooms for adults, Knowles found that adult learners need to know why they are learning something to be engaged; adults learn best when new skills are practical and useful. When we teach relevant subject matter to adults, we need to be mindful of these androgogical principles.

If you are interested in exploring the scholarship of teaching beyond librarianship, a number of organizations and journals are worth your time. The Campbell Collaboration (http://www.campbellcollaboration.org/), for example, is a worldwide research collaboration that looks at the effects of educational interventions. Over the last several years, some interesting debates about teaching have taken place in journals such as Medical Education (http://www3.interscience.wiley.com/journal/117964731/home), Medical Teacher (http://www.informaworld.com/smpp/ title $\sim$ content $=$ t713438241), and Academic Medicine (http://journals.lww.com/academicmedicine) (also see Appendix A). In addition, these journals present additional publishing venues for health librarians.

\section{EBT principles for the future}

I want to advance an ambitious and encompassing model for evidence-based education. This model would take advantage of new information technologies, as well as the spirit of open-access publishing that is emerging in the science on the Web [21].

When we teach millennial students today, the traditional talk and chalk methods of the past are no longer sufficient [22]. The importance of being accessible and relevant to millennial students and reviewing evidence in our field to help us understand their evolving needs is critical. Most health programmes, for example, have moved to cases to create active learning opportunities for students. The premise behind social forms of learning is that knowledge is more likely to be retained when students are involved in their own learning. Similarly, in PBL, learning occurs within a context of problem resolution that puts theory into action in a way that resembles professional and lifelong learning practices. 
Self-directed learning is certainly the pedagogy of the moment. Vygotsky used a number of powerful metaphors to help learners, such as bridging, providing "zones" for optimal learning, building self-efficacy, and competencies [23]. Other ideas include the fact that deep learning takes place in democracies where structures are egalitarian and nonthreatening. The idea of flattened democratic hierarchies is a throwback to John Dewey who said that "teaching and learning should involve the preparation of learners for their active participation as citizens" [24]. Health librarians will want to heed Dewey's advice in order to prepare health professionals for the future in a more democratic world.

\section{Conclusion}

Evidence-based teaching lacks a coherent definition, but much can be gained by analyzing how teaching is viewed in education and medicine itself. As teachers, health librarians will want to be aware of the debate about the limits of EBT and create their own teaching models. In the EBM movement, Greenhalgh $[25,26]$ has emphasized the need to strike a balance between evidence-based and narrative-based solutions; this "meta" approach seems to be a sensible solution for health librarians as well. Finally, if the teaching and learning series has emphasized anything, it's that theoretical and practical foundations are needed for all health librarians, particularly those who espouse the principles of EBT.

\section{References}

1. HLWIKI Canada. Evidence-based teaching for health librarians. 2010 Jan 18.

2. Giustini D. Utilizing learning theories in the digital age: an introduction for health librarians. Part I. J Can Health Libr Assoc. 2008 Sep;29(3):109-15.

3. Giustini D. Utilizing learning theories in the digital age: from theory to practice. Part II. J Can Health Libr Assoc. 2009 Mar;30(1):19-25.

4. Giustini D. Tipping point(s): informal learning for health librarians in an economic downturn. Part III. J Can Health Libr Assoc. 2009 Sep;30(3):113-16.

5. Koufogiannakis D, Crumley E. Evidence-based librarianship. Feliciter. 2002;(2):112-14.

6. Hopkins FL. A century of bibliographic instruction: The historic claim to professional and academic legitimacy. Coll Res Libr. 1982 May;43:192-98.

7. Brettle A. Evaluating information skills training in health libraries: a systematic review. Health Info Libr J. 2007 Dec;24 Suppl 11:18-37.

8. Bradley DR, Rana GK, Martin PW, Schumacher RE. Realtime, evidence-based medicine instruction: a randomized controlled trial in a neonatal intensive care unit. $\mathrm{J} \mathrm{Med} \mathrm{Libr}$ Assoc. 2002;(90):194-201.

9. Koufogiannakis D, Wiebe N. Effective methods for teaching information literacy skills to undergraduate students: a systematic review and meta-analysis. Evid Based Libr Inf Pract. 2006;(1):3-43.
10. Brettle A. Evaluating information skills training in health libraries: a systematic review. Health Info Libr J. 2007 Dec;24 Suppl 1:18-37.

11. Partridge H, Hallam G. Educating the millenial generation for evidence based information practice. Libr Hi Tech. 2006; 24(3):400-19.

12. Schardt C. Evidence based medicine and the hospital librarian. J Hosp Librarian. 2001;1(2):1-14.

13. Booth A, Brice A. Evidence based practice for information professionals: a handbook. London: Facet Publishing, 2004.

14. Guyatt G, Cairns J, Churchill D, et al. Evidence-Based Medicine Working Group. Evidence-based medicine. A new approach to teaching the practice of medicine. JAMA. 1992; 268:2420-5.

15. Sackett DL. Evidence based medicine: what it is and what it isn't. BMJ. 1996;312:71-2.

16. Davies P. What is evidence-based education? Br J Educ Stud. 1999;47(2):108-22.

17. Hammersley M. Some questions about evidence-based practice in education. British Educational Research Association Annual Conference; 2001 Sep 13-15; Leeds, UK. Leeds University, 2001.

18. Booth A, Brice A. Evidence based practice for information professionals: a handbook. London: Facet Publishing, 2004.

19. Peacock J. Teaching skills for teaching librarians: postcards from the edge of the educational paradigm. Aust Acad Res Libr. 2001:26-42.

20. Knowles MS. The adult learner: a neglected species. Houston: Gulf Publishing Company, 1990.

21. Willinsky J. Extending the prospectus of evidence-based education. Insight. 2001;1(1).

22. Peacock J. Teaching skills for teaching librarians: postcards from the edge of the educational paradigm. Aust Acad Res Libr. 2001:26-42.

23. Vygotsky L. Problems of method. In: Mind in Society. Cambridge, MA: Harvard University Press, 1978.

24. Dewey J. Experience and education. New York: MacMillan, 1938.

25. Greenhalgh T. Narrative based medicine: narrative based medicine in an evidence based world. BMJ. 1999;318:323-25.

26. Greenhalgh T, Hurwitz B. Narrative based medicine: why study narrative? BMJ. 1999;318:48-50.

\section{Appendix A}

\section{Other relevant EBT literature}

- Bayley L, McKibbon KA. Evidence-based librarianship: a personal perspective from the medical/nursing realm. Libr Hi Tech. 2006;24(3):400-419.

- Dickinson GK. How one child learns: the teacherlibrarian as evidence-based practitioner. Teach libr. 2005;33(1):16-20. 
- Evans J, Benefeld P. Systematic reviews of educational research: does the medical model fit? Br J Educ Stud. 27:5:527-42.

- Greenhalgh T, Toon P, Russell J, Wong G, Plumb L, Macfarlane F. Transferability of principles of evidence based medicine to improve educational quality: systematic review and case study of an online course in primary care. BMJ. 2003;326:142-45.

- Harden et al. The good teacher is more than a lecturer: the twelve roles of the teacher. Med Teach. 2000;22(4):334-47.

- Hammersley M. Some questions about evidence-based practice in education. British Educational Research Association Annual Conference; 2001 Sep 13-15; Leeds, UK. Leeds University, 2001.

- Hargreaves DH. Teachers, educational research and evidence-based teaching Educ Rev. 1996;10(2):46-50.

- Hargreaves D. In defence of research for evidencebased teaching: A rejoinder to Martyn Hammersley. $\mathrm{Br}$ Educ Res J. 1997;23(4):405-19.

- Hopkins FL. A century of bibliographic instruction: the historic claim to professional and academic legitimacy. Coll Res Libr. 1982;43:192-98.

- Hunsucker R. The theory and practice of evidencebased information work-one world? Laval University.

- Kaestle CF. The awful reputation of educational research. Educational Researcher. 1993;22(1):23, 26-31.

- Mosteller F, Boruch R, editors. Evidence matters: randomized trials in education research. Washington, DC: Brookings, 2002.

- Schön DA. The reflective practitioner: how professionals think in action. New York: Basic Books, 1983.
- Slavin RE. Evidence-based educational policies: Transforming educational practice and research. Educational Researcher. 2002;31:15-21.

- Slawson DC, Shaughnessy AF. Teaching evidencebased medicine: should we be teaching information management instead? Acad Med. 2005;80:685-89.

- Todd RJ. Evidence based practice: the sustainable future for teacher- librarians. Scan. 2002;21:30-7.

- Wenger E. Communities of practice: Learning, meaning, and identity. Cambridge, UK: Cambridge University Press, 1998.

\section{Evidence-based teaching Web sites}

- Adult Literacy Education (ALE) Wiki: http://wiki. literacytent.org

- An Evidence-Based Adult Education Program Model Appropriate for Research: http://www.ncsall.net/fileadmin/ resources/research/op_comings4.pdf

- Association for Medical Education: http://www.amee. org

- BEME (Best Evidence Medical Education) Collaboration: http://www.bemecollaboration.org/

- CEM - Evidence based education: http://www.cemcentre. org

- HLWIKI Canada, Research for librarians - portal, January 2010: http://hlwiki.slais.ubc.ca/index.php/ Research_for_librarians_-_portal

- US Department of Education, Evidence-Based Education: http://www.ed.gov/nclb/methods/whatworks/eb/ edlite-index.html 